\title{
Legal Certainty in Simple Evidence Related to Inside Electronic Proof Tools the Legal Procedure Of The Bankruptcy
}

\author{
Sahat Tambunan \\ \{sahattambunanlaw@yahoo.com\} \\ Doctor of Law, Universitas Jayabaya, Jakarta, Indonesia
}

\begin{abstract}
Simple proof in a bankruptcy application is proof of the fact that there are two or more creditors and there are debts that are due and can be collected that are not paid in full by the debtor. A problem that often occurs and is the topic of this research is the problem of two decisions from the Commercial Court Judges, some of which reject and accept BI checking as the existence of other creditors in a bankruptcy case. The method in this study uses normative, this type of research is qualitative research that is field research and library research, with a philosophical, statutory, conceptual, comparative, and casuistic approach. The results of the study found that the implementation of simple evidence (Sumir) related to electronic evidence in the current Bankruptcy Procedure Law is not in accordance with the principles in the Principal Commercial Court contained in the general explanation of the sixth paragraph of Law Number 37 of 2004 concerning the Bankruptcy Law and PKPU, namely the principle, " fair, fast, open, and effective, regarding the existence of other creditors through the BI Checking proof process must become jurisprudence, because BI Checking is a product / output produced by the Debtor Information System (SID) and is legal and official banking information and is managed by the Bank Indonesia electronically, in order to realize legal certainty, in simple proof (sumir) related to BI Checking as the existence of another creditor requires a temporary legal certainty in Article 8 paragraph (4) of the Bankruptcy Law and PKPU, does not explicitly regulate simple evidence related to electronic evidence, thus giving rise to contrasting judges' decisions addictive.
\end{abstract}

Keywords: Proof; Sumir; Bankruptcy, Electronic evidence.

\section{Introduction}

Every company has a legal form which is the statute. This legal form shows the legality of the company as a business entity that carries out economic activities. Bankruptcy in the business world is possible with certain forms of business. In simple terms, a company can be classified into 4 (four) forms of business, namely: individual company (individual), partnership (partnership and limited partnership), limited liability company (limited liability company), cooperative (cooperative). A business does not always run smoothly and smoothly, often the business actor's financial condition is such that it reaches a state of stopping paying, that is, a situation in which the business actor is no longer able to pay his debts that are due.

When carrying out activities in the business sector, lending and borrowing activities are activities that must be carried out by a business entity. Lending and borrowing in a business entity function to increase capital or funds for the smooth operation of the company. The 
existing trend shows that a company is in dire need of capital from this borrowing and lending, and more and more companies are not using capital or additional funds from third parties or capital from outside the company.

In legal practice, often a debtor (the debtor) fails to fulfil his obligations or achievements, not because of a compelling situation (overmatch). Such a situation is known as breaking the promise (default). In civil law, there are three forms of default, namely: 1 . The debtor does not fulfil any performance at all; 2. The debtor is late in meeting achievements; 3 . A debtor with improper performance. The bankruptcy process begins with an application for bankruptcy against a debtor who meets the requirements, in accordance with Article 2 paragraph 1 of the Bankruptcy and PKPU Law, which states: "A debtor who has two or more creditors and does not pay off at least one overdue debt can be invoiced.

In legal practice, there are several problems with the enforcement and application of bankruptcy law, one of which is the interpretation and application of the provisions of Article 8 paragraph (4) of the Bankruptcy Law and PKPU. The problem is that there are two decisions from the Commercial Court Judge, some of which reject and accept BI checking as to the existence of other creditors in the bankruptcy case. One of the proofs of the existence of the debt is by means of a creditor proving that he has given a warning to the debtor to pay his obligations, but the debtor has not paid it. Or the creditor proves that until the pre-agreed period of payment of the obligation (debt) has passed, the debtor has not paid his debt. If proving the existence of the debt is quite complicated and difficult or still creates disputes, then it does not meet the simple proving requirements.

Whereas with regard to proving the existence of the debt, it must be clear that the debt is a debt that the debtor cannot deny. Whereas the debtor has been reprimanded by the creditor for fulfilling his debt obligation, but the debtor has not fulfilled this obligation. Or if it has been determined with certainty the time to fulfil the debtor's obligations, after that period the debtor does not fulfil his obligations. Problems that often occur in terms of proving the inconsistency of the Commercial Court panel in terms of whether other creditors are required to be present in terms of proof such as BI Checking evidence, the application for bankruptcy declaration was rejected by the panel of judges. According to the Judge, the BI Checking product letter evidence still needed supporting evidence because the defendant rejected the petitioner's arguments. Yet based on Article 1866

The Civil Code states that the means of evidence are letters or writings, witnesses, alleged confessions, and oaths. Written evidence is the main evidence in a civil case so that it is placed first or at the top. Since the ITE Law, there have been additional types of evidence at court, namely electronic information and/or electronic documents. In the general provisions of the ITE Law, it can be seen that types of electronic data such as writing, photos, sounds, images are electronic information, while electronic information such as writing, photos, sounds, images stored on a flash disk that can be opened via a computer device is an electronic document.

The position of electronic evidence as evidence in the Indonesian legal system itself, both criminal and civil, does not yet have a clear status. The existence of electronic evidence as evidence is still very low. In presenting electronic evidence as valid and independent evidence, it must be able to guarantee that the recording or data runs in accordance with the applicable provisions.

Lack of inconsistency in Supreme Court decisions and commercial court decisions in determining the existence of summier evidence between one decision and another in a bankruptcy case. One of the cases of filing an application for bankruptcy was made by the creditor holding the last cessie right (cessionaries). In this study, the commercial court panel of judges considered simple proof of the creditors' obligation to notify debtors in bankruptcy. 


\section{Research Methods}

This research as a form of scientific research is compiled using a specific research method, namely the juridical-normative research method. The normative juridical approach, namely legal research which is carried out by examining library materials or secondary data as the basic material for research by searching for statutory regulations and literature related to the problems under study to examine the application of rules or norms in positive law. This type of research is qualitative research that is field research and library research, with philosophical, statutory, conceptual, comparative, and casuistic approaches.

\section{Results and Discussion}

The principle of proof is that the judge is obliged to give the burden of proof to the plaintiff to prove the arguments or events that can support the argument submitted by the plaintiff, while for the defendant, the judge is obliged to provide a burden of proof to prove his rebuttal to the arguments presented by the plaintiffs. Judges should not literally carry out the principle of proof, but judges must be wise and appropriate, that is, the judge should place the obligation to prove to the easiest party to prove, and not burden the party who is most difficult to prove, especially in cases based on a legal relationship arising without written evidence or letters (made orally) by the parties.

Arrangements regarding the simple proof as mentioned previously are contained in the provisions stipulated in the provisions of Article 8 paragraph (4) UUK PKPU and Article 2 paragraph (1) of the Bankruptcy and PKPU Law. Whereas what must be proved simply is the bankruptcy requirements in Article 2 paragraph (1) of the Bankruptcy Law and PKPU, namely: There are two or more creditors. Creditors are people who have receivables due to agreements or laws that can be collected in court. "Creditors" here include both concurrent creditors, separatist creditors, and preferred creditors. Then there are debts that have matured and can be collected that are not paid in full by the debtor. This means that there is an obligation to pay debts that have matured, either because they have been agreed upon, because of the acceleration of the collection period as agreed, due to the imposition of sanctions or fines by the competent authority, or because of a court, arbitrator, or arbitral tribunal decision.

Talking about evidence in a bankruptcy case, the connection with the provisions of Article 299 of the Bankruptcy Law and PKPU states that Unless this Law stipulates otherwise, the applicable procedural law is the Civil Procedure Law (HIR / RBg). Until now, the regulations regarding the specificity of the Commercial Court procedural law have not been carried out explicitly and specifically.

The current procedural law for the Commercial Court is separated according to the object of the dispute being submitted. To date, there are two issues and two laws governing the appointment of the Commercial Court as a dispute resolution institution, namely the Law on Bankruptcy and the Law on Intellectual Property Rights. The procedural law used by the Commercial Court in bankruptcy cases is basically guided by Law Number 37 of 2004 concerning Bankruptcy and Postponement of Debt Payment Obligations. If concluded, the procedural law in the Commercial Court in bankruptcy cases, apart from referring to the provisions of Article 299 UUK-PKPU, also has special characteristics, including Simple Evidence, the system of proof adopted, which is simple in nature or proving in summary. The application for a bankruptcy statement must be granted if there are facts that can be simply 
proven that the statement to declare bankruptcy has been fulfilled. BI Checking as electronic evidence as evidence that an electronic transaction has been legally accepted under Indonesian law.

As stated in Article 5 paragraph (1) of the ITE Law: "Electronic information and/or Electronic Documents and/or their printouts are valid legal evidence. "This is reinforced by the provisions in Article 5 paragraph (2) of the ITE Law that" Electronic Information and/or Electronic Documents and/or their printouts as referred to in paragraph (1) are an extension of valid evidence in accordance with the applicable procedural law in Indonesia. According to Article 1866 of the Civil Code, valid evidence consists of written evidence, evidence with witnesses, allegations, confessions, and oaths.

Meanwhile, according to Article 184 of the Criminal Procedure Code, valid evidence consists of witness statements, expert statements, letters, instructions, and statements from the defendant. Therefore, evidence according to the above procedural law which is made in the form of electronic information / electronic documents, and electronic information / electronic documents itself, is valid evidence according to the ITE Law. The ITE Law stipulates that electronic information / electronic documents and/or printouts are valid legal evidence, and are an extension of valid evidence in accordance with the applicable procedural law in Indonesia. The expansion in question is the recognition of information and/or electronic documents along with the printed results as valid evidence in court, so that currently there is one more evidence in court that previously did not exist.

With a simple proof of the existence of other creditors in BI Checking, it can provide legal certainty in the decision, this is in line with the opinion of Jan Michael Otto that the state or judicial institutions need to meet several requirements, namely: First, clear legal rules are available or clear, consistent and easy to obtain, issued by the power of the state. Second, the ruling agencies apply these legal rules consistently and also obey and obey them. Third, the majority of citizens in principle agree with the content of the rules and accordingly adjust their behaviour towards the rules. Fourth, independent and impartial judges apply these legal rules consistently when they resolve legal disputes. And fifth, that the judicial decisions are concretely implemented. With the existence of other creditors in BI Checking, simple proof can be fulfilled as one of the conditions for bankruptcy, because the proof is simple, so the existence of the ITE Law is very much needed in a simple proof process.

The provisions regarding simple proof of bankruptcy and PKPU as contained in the current KPKPU Law are very simple for the current global economic development. This provision has not been supported by a strong bankruptcy requirement system regarding the facts of debts and creditors, this is then fully submitted to the Judge to interpret the petition as simple or not simple if the requirements as referred to in Article 2 paragraph (1) are fulfilled the judge must declare bankruptcy.

With the development of science, communication, and information technology, rapid economic conditions, and the development of complex cross-territorial dimensions of civil relations, it will be difficult to measure the simple criteria referred to in Article 8 paragraph (4) of the KPKPU Law. Therefore, it will be very difficult for Judges to test existing petitions unless the bankruptcy system in the KPKPU Law contains strict regulations regarding proof through tests of Debtor liquidity which are carried out at trial so that the Judge can factually assess the submitted application.

The provisions regarding simple proof of bankruptcy and PKPU as contained in the current KPKPU Law are very simple for the current global economic development. This provision has not been supported by a strong bankruptcy requirement system regarding the facts of debts and creditors, this is then fully submitted to the Judge to interpret the petition as simple or not simple 
if the requirements as referred to in Article 2 paragraph (1) are fulfilled the judge must declare bankruptcy.

With the development of science, communication, and information technology, rapid economic conditions, and the development of complex cross-territorial dimensions of civil relations, it will be difficult to measure the simple criteria referred to in Article 8 paragraph (4) of the KPKPU Law. Therefore, it will be very difficult for Judges to test existing petitions unless the bankruptcy system in the KPKPU Law contains strict regulations regarding proof through tests of Debtor liquidity which are carried out at trial so that the Judge can factually assess the submitted application.

\section{Conclusion}

Whereas the implementation of simple evidence (Sumir) related to electronic evidence in the current Bankruptcy Procedure Law is not in accordance with the principles in the Principal Commercial Court contained in the general explanation of the sixth paragraph of Law Number 37 of 2004 concerning the Bankruptcy Law and PKPU, namely the principle of, "fair, fast open, and effective, regarding the existence of other creditors through the BI Checking proof process must become jurisprudence, because BI Checking is a product / output produced by the Debtor Information System (SID) and is legal and official banking information and is electronically managed by Bank Indonesia, in order to realize legal certainty, in simple evidence (sumir) related to BI Checking as the existence of another creditor requires a temporary legal certainty in Article 8 paragraph (4) of the Bankruptcy Law and PKPU, does not explicitly regulate simple evidence related to electronic evidence, giving rise to contradictory judges' decisions.

\section{References}

[1] Patrik, Purwahid. (1994) Dasar-Dasar Hukum Perikatan (Perikatan Yang Lahir Dari Perjanjian Dan Dari Undang-Undang), Bandung: CV. Mandar Maju.

[2] Subhan, M. Hadi (2008) Hukum Kepailitan, Prinsip, Norma, dan Praktik di Peradilan, Jakarta Kencana.

[3] Muljadi, Kartini \& Gunawan Widjaja (2003) Pedoman Menangani Perkara Kepailitan. Jakarta: Raja Grafindo Persada

[4] Makarim, Edmon (2005) Pengantar Hukum Telematika, Jakarta: Raja Grafindo Persada.

[5] Zulaeha, M. (2015) Mengevaluasi pembuktian sederhana dalam kepailitan sebagai perlindungan terhadap dunia usaha di Indonesia. JHAPER, 1(1).

[6] Hartini, Rahayu (2009) Penyelesaian Sengketa Kepailitan di Indonesia, Jakarta: Kencana Prenada Media. 